\title{
EFFECTS OF CROSSING OF DOMESTIC BREED WITH BEEF BREEDS ON THE QUALITY OF MEAT IN PR CHINA AND REPUBLIC OF SERBIA
}

\author{
S. Aleksić ${ }^{1}$, Sun Fang ${ }^{2}$, Liu Di ${ }^{3}$ M.M. Petrović ${ }^{1}$, V. Pantelić ${ }^{1}$, N. Stanišić ${ }^{1}$, D. \\ Ostojić-Andrić́ ${ }^{1}$, M. Petričević ${ }^{1}$, D. Nikšić ${ }^{1}$, N. Delić ${ }^{1}$ \\ ${ }^{1}$ Institute for Animal Husbandry, 11080 Belgrade, Republic of Serbia \\ ${ }^{2}$ Institute of Animal Husbandry, Heilongjiang Academy of Agricultural Sciences, Harbin, PR China \\ ${ }^{3}$ Heilongjiang Academy of Agriculture Science, Harbin, China \\ Corresponding author: saleksic@mail.com \\ Communication
}

\begin{abstract}
This paper presents the results of crossing Domestic Spotted breed with beef cattle breeds in the People's Republic of China and the Republic of Serbia. China is a big country of beef production and consumption. In 2012, beef production in China was 5,540,000 tons, which accounted for $9.7 \%$ of the global beef production, ranking the third in the world. The main sources of China's beef are from crossbreeding cattle (native breed crossbred with foreign beef cattle). Simmental cattle are the most-widely used beef cattle in China's improved beef cattle. China has cultivated its own Simmental after over 40 years' crossbreeding and improvement. China's consumers mainly have three demands for beef quality as follows: expensive beef produced from Wagyu crossbreed with better marbling; lean beef from Simmental, Charolais and Limousin crossbreeds, top parts supplied to hotels while common parts to supermarkets; veal from cow calves. Chinese researchers are carrying out researches which are centered on marbling beef, lean beef and veal on complete techniques of good breed, feeding management, slaughter and cutting and carcass classification. At present, researchers have lively interest in functional genomics of meat quality traits of cattle, they expect to use these methods to study meat quality traits and then improve the meat quality. Improved cattle breeds universally utilized in China are mainly Simmental followed by Charolais, Limousin, Wagyu and Angus. Other three cattle breeds including Belgian blue cattle, Piedmontese and Gelbvien have ever been applied, however, rarely used in present beef cattle production. Republic of Serbia has in the future to quickly and efficiently provide adequate quantities of top quality meat. One of the ways to increase the yield and quality of the meat is crossing of Domestic spotted cattle of lower production traits with French beef cattle breeds. Beef production in the EU is adapted to the consumer taste. Meat must have a light red colour, equally suffused with fat and with pronounced sensory characteristics
\end{abstract}


such as tenderness, juiciness, flavour and aroma. The results on the quality of meat of F1 generation crosses (Domestic Spotted breed with French beef cattle breeds Charolais and Limousine) indicate that by industrial crossing beef, meat-packing and organoleptic characteristics of meat can be improved.

Key words: cattle breeding, crossing, meat quality, the People's Republic of China, Republic of Serbia

\section{Introduction}

China is a big country of beef production and consumption. In 2012, beef production in China was 5,540,000 tons, which accounted for $9.7 \%$ of the global beef production, ranking the third in the world; China, ranking as the fourth largest beef consumer, consumed 5,524,000 tons of beef in 2012, which was $9.95 \%$ of the global beef consumption. In spite of this, China's Per-capita consumption of beef is $4.2 \mathrm{~kg}$, ranking $26^{\text {th }}$ all over the world (USDA, World Markets and Trade, In selected countries). Compared to 2011, China turned net export into net import of 49,204.13 tons of beef in 2012, and imported 61,404.41 tons of beef with the average price of $\$ 4,146.70$ / ton. Due to the BSE in Brazil, China greatly increased beef import from Australia, and it will become the fourth largest beef exporter of Australia on June 30, 2013, with the import skipping from 6,000 tons one year ago to 50,000 tons according to the statistics given by a governmental research organization called the Australian Bureau of Resource Economics and Science. In 2012, China exported 12,200.29 tons of beef with the price of $\$ 6,582 /$ ton (From: Integrated Information Network of China Customs - www.haiguan.info). The beef cattle slaughtered in China in 2012 was 24,000,000; year-end beef cattle stock was $65,000,000$; the average carcass weight of crossbreeding cattle was $217 \mathrm{~kg} / \mathrm{head}$ and that of yellow cattle (native breed) was $190 \mathrm{~kg} / \mathrm{head}$; yaks slaughtered was 2,070,000; year-end yak stock was 19,800,000; the average carcass weight of yaks was $120 \mathrm{~kg} / \mathrm{h}$ ead (Cao Bing-hai, the chief scientist of China's cattle and yak industrial technology system).

Keeping in mind the needs of the developed countries to import highquality beef, Republic of Serbia has in the future to quickly and efficiently provide adequate quantities of top quality meat. One of the ways to increase the yield and quality of the meat is crossing of Domestic spotted cattle of lower production traits with French beef cattle breeds (Čobić et al., 1990; Aleksić et al., 1995, 1998,1999 and Cepin, 2001). Given that the population of Domestic Spotted cattle of lower production performance is a significant part of the population the total cattle population of Serbia, by breeding/improving this population, significant results in the production of quality beef would be achieved. 
Beef production in the EU is adapted to the consumer taste. Meat must have a light red colour, equally suffused with fat and with pronounced sensory characteristics such as tenderness, juiciness, flavour and aroma (Aleksić et al., 2001,2005,2006,2009). EU member states exert a unified classification by socalled SEUROP system according the development of adipose tissue (1-5) (Ostojić-Andrić et al., 2012). Factors affecting the quality of meat can be divided into pre mortal Dikcman et al. (2005) (genetic basis, housing, preparation for slaughtering, etc.) and post mortal (slaughtering procedure and cooling of meat) Thompson (2002). Research indicates small differences in sensory traits of meat from different genotypes, and authors explanations is that they are mainly caused by the physiological age, since different breeds of the same age don't have the same slaughter maturity (Harrington, 1985, Bucher, 1985).

\section{PR CHINA- Meat quality (crossing domestic breed $x$ beef breeds) China beef production and trade in 2012}

\section{The application of world's beef cattle breeds introduced to China}

The main sources of China's beef are from crossbreeding cattle (native breed crossbred with foreign beef cattle), yaks, water buffalo in the south, and southern yellow cattle and Holstein bulls are becoming new sources supplying China beef. Improved cattle breeds universally utilized in China are mainly Simmental followed by Charolais, Limousin, Wagyu and Angus. Other three cattle breeds including Belgain blue cattle, Piedmontese and Gelbvien have ever been applied, however, rarely used in present beef cattle production.

\section{Research on beef quality in China}

\section{Research process in functional genomics of meat quality traits of cattle}

With the rapid development of China's economy, Chinese consumers have a fast growing beef consumption and higher demand for beef quality. The important indicators which affect the beef quality are marbling and tenderness, and those with good marbling and tenderness are favored by consumers. Studies have proved that beef marbling is highly related to beef tenderness and flavor, it can increase the tenderness, juiciness and flavor. At present, researchers have lively interest in functional genomics of meat quality traits of cattle, they expect to use these methods to study meat quality traits and then improve the meat quality.

Zhou Guoli et al.(2005) showed that Haelll-RFLP of a mutated enzyme cutting site on intron 2 was found in H-FAPB gene of Luxi cattle (native beef cattle in Shandong province) by PCR-RFLP method. By applying least square principle 
linear model to conduct a significance test for effect of molecular marker genotypes on meat quality including marbling grade and tenderness trait, the results showed that BB homozygous genotype in H-FABP gene of Luxi cattle had a greater impact on shearing force of beef tenderness $(\mathrm{P}<0.05)$; while, differences among three genotypes $\mathrm{AA}, \mathrm{AB}$ and $\mathrm{BB}$ were not significant for the grading of marbling.

A study by Wen Li-zheng et al. (2008) proved that Heart Fatty acid-binding proteins (H-FABP) could be used as candidate gene of improving the tenderness of red steppe cattle or QTL of meat traits. Another study by Wen Li-zheng et al. (2008) showed that H-FABP gene had a significant influence on the tenderness of red steppe cattle, and it could be a major gene affecting its tenderness.

\section{Determination on Beef quality index}

Research on beef quality of different breeds

In June, 2006, Zhou Lei et al. (2007) conducted an experiment to study the longissimus dorsi between 11-13 ribs of left half carcass of six cattle, including Holstein cattle, Holstein crossbreed (Holstein $\times$ Xinjiang brown cattle), yellow cattle, Xinjiang brown crossbreed (Xinjiang brown cattlexyellow cattle), Xinjiang brown cattle and Simmental crossbreed (Simmental $\times$ Xinjiang brown cattle). The determination was including myoglobin, water binding capacity, cooking loss, shearing force, collagen, moisture content, crude protein, intramuscular fat content. Results reflected that the flesh color, tenderness, protein, intramuscular fat content and other beef quality indexes of Xinjiang brown cattle were better than the other five breeds. Xinjiang brown cattle's crossbreeding with Holstein cattle and yellow cattle respectively made the shearing force value and collagen content respectively decrease by $1.26 \%, 6.31 \%$ and $5.34 \%, 8.57 \%$; protein and intramuscular fat content respectively increased by $2.65 \%, 2.32 \%$ and $7.87 \%, 27.83 \%$. Myoglobin content respectively increased by $5.36 \%$ and decreased by $8.20 \%$. Xinjiang brown cattle had better improved beef quality of Holstein and yellow cattle. Detailed figures are shown in table 1.

Simmental cattle are the most-widely used beef cattle in China's improved beef cattle. China has cultivated its own Simmental after over 40 years' crossbreeding and improvement.

Niu Lei et al. (2011) conduced an experiment to assess the beef qualities of different parts on Chinese Simmental. They chose twelve 18-month Chinese Simmental cattle and slaughtered, took four parts including supraspinatus, longissimus dorsi, psoas major muscle and semitendinosus on the left half-carcass of each cattle and chilled at $4{ }^{\circ} \mathrm{C}$ for 42 -hour, and then conducted assessment for their physical indexes (cooking loss, shearing force, $\mathrm{pH}$ and flesh color), nutritional qualities (fat, protein and water content) and sensory evaluations (tenderness, 
juiciness and flavor). SPSS17.0 statistical analysis software was utilized with methods of LSD and Duncan in order to do variance analysis.

Table 1 Results of physical and chemical beef quality traits from six beef breed

\begin{tabular}{|l|c|c|c|c|c|c|}
\hline & Holstein & $\begin{array}{l}\text { Xinjiang Brown } \\
\times \text { Holstein }\end{array}$ & Yellow Cattl e & $\begin{array}{l}\text { Xinjiang Brown } \\
\times \text { Yellow Cattle }\end{array}$ & $\begin{array}{l}\text { Xinjiang } \\
\text { Brown }\end{array}$ & $\begin{array}{l}\text { Xinjiang } \\
\text { Brown } \\
\times \text { Simmental }\end{array}$ \\
\hline $\begin{array}{l}\text { Myoglobin(u } \\
\text { mol/g) }\end{array}$ & $0.112 \pm 0.002^{\mathrm{abc}}$ & $0.118 \pm 0.007^{\mathrm{abc}}$ & $0.122 \pm 0.007^{\mathrm{a}}$ & $0.112 \pm 0.004^{\mathrm{abc}}$ & $0.104 \pm 0.002^{\mathrm{bc}}$ & $0.100 \pm 0.008^{\mathrm{bc}}$ \\
\hline $\begin{array}{l}\text { Rate } \\
\text { dehydrate(\%) }\end{array}$ & $17.96 \pm 1.15^{\mathrm{b}}$ & $21.84 \pm 1.02^{\mathrm{a}}$ & $21.42 \pm 0.82^{\mathrm{a}}$ & $20.06 \pm 1.04^{\mathrm{ab}}$ & $22.11 \pm 0.98^{\mathrm{a}}$ & $21.62 \pm 1.22^{\mathrm{a}}$ \\
\hline $\begin{array}{l}\text { Water } \\
\text { holding } \\
\text { capacity(\%) }\end{array}$ & $76.35 \pm 1.50^{\mathrm{a}}$ & $71.34 \pm 1.27^{\mathrm{b}}$ & $72.19 \pm 1.00^{\mathrm{b}}$ & $73.73 \pm 1.30^{\mathrm{b}}$ & $71.35 \pm 1.29^{\mathrm{b}}$ & $71.62 \pm 1.62^{\mathrm{b}}$ \\
\hline $\begin{array}{l}\text { Cooking } \\
\text { loss(\%) }\end{array}$ & $31.87 \pm 0.48$ & $34.21 \pm 0.82$ & $33.01 \pm 1.97$ & $33.94 \pm 0.61$ & $34.50 \pm 0.88$ & $33.78 \pm 0.73$ \\
\hline $\begin{array}{l}\text { Shear } \\
\text { force(kg) }\end{array}$ & $7.92 \pm 0.34$ & $7.82 \pm 0.32$ & $8.08 \pm 0.39$ & $7.57 \pm 0.21$ & $6.85 \pm 0.65$ & $7.55 \pm 0.53$ \\
\hline $\begin{array}{l}\text { Total } \\
\text { collegen(mg/ } \\
\text { g) }\end{array}$ & $6.56 \pm 0.32$ & $6.21 \pm 0.39^{\mathrm{a}}$ & $6.77 \pm 0.51^{\mathrm{a}}$ & $6.19 \pm 0.34^{\mathrm{a}}$ & $5.06 \pm 0.35^{\mathrm{b}}$ & $6.14 \pm 0.21^{\mathrm{b}}$ \\
\hline
\end{tabular}

Beef quality assessment on different parts of Chinese Simmental

Niu Lei et al. (2011) conduced an experiment to assess the beef qualities of different parts on Chinese Simmental. They chose twelve 18-month Chinese Simmental cattle and slaughtered, took four parts including supraspinatus, longissimus dorsi, psoas major muscle and semitendinosus on the left half-carcass of each cattle and chilled at $4{ }^{\circ} \mathrm{C}$ for 42 -hour, and then conducted assessment for their physical indexes (cooking loss, shearing force, $\mathrm{pH}$ and flesh color), nutritional qualities (fat, protein and water content) and sensory evaluations (tenderness, juiciness and flavor). SPSS17.0 statistical analysis software was utilized with methods of LSD and Duncan in order to do variance analysis. When synthesizing physical indexes and sensory evaluations of nutrition, results displayed that the beef quality of psoas major muscle was better while that of semitendinosus was worse. There were no significant differences $(P>0.05)$ among all the tested parts in water content and flesh color while significant differences $(\mathrm{P}<0.05)$ existed in other indexes. Detailed figures are shown in table 2. 
Table 2 Results of physical beef quality traits for different parts of beef from Chinese Simmental

\begin{tabular}{|c|c|c|c|c|c|c|}
\hline & $\begin{array}{c}\text { Cooking loss } \\
(\%)\end{array}$ & $\begin{array}{c}\text { Shear force } \\
(\mathrm{kg})\end{array}$ & $\mathrm{pH}$ & \multicolumn{3}{|c|}{ Colour } \\
\cline { 5 - 7 } & & $\mathrm{L}^{*}$ & $\mathrm{a}^{*}$ & $\mathrm{~b}^{*}$ \\
\hline M.supraspinatus & $38.92 \pm 3.06^{\mathrm{b}}$ & $5.93 \pm 1.35^{\mathrm{a}}$ & $5.98 \pm 0.19^{\mathrm{c}}$ & $40.50 \pm 2.62^{\mathrm{a}}$ & $22.98 \pm 2.14$ & $10.92 \pm 2.14^{\mathrm{a}}$ \\
\hline $\begin{array}{c}\text { M. longissimus } \\
\text { dorsi }\end{array}$ & $34.21 \pm 2.89^{\mathrm{a}}$ & $7.14 \pm 1.29^{\mathrm{b}}$ & $5.64 \pm 0.18^{\mathrm{ab}}$ & $41.74 \pm 3.56^{\mathrm{ab}}$ & $23.74 \pm 3.40$ & $12.89 \pm 2.28^{\mathrm{a}}$ \\
\hline M. psoas major & $32.71 \pm 3.42^{\mathrm{a}}$ & $5.43 \pm 0.70^{\mathrm{a}}$ & $5.74 \pm 0.14^{\mathrm{b}}$ & $43.98 \pm 3.23^{\mathrm{b}}$ & $24.07 \pm 3.44$ & $11.17 \pm 3.21^{\mathrm{a}}$ \\
\hline M.semitendinosus & $38.65 \pm 2.44^{\mathrm{b}}$ & $7.67 \pm 1.06^{\mathrm{b}}$ & $5.55 \pm 0.14^{\mathrm{a}}$ & $49.40 \pm 3.87^{\mathrm{c}}$ & $24.74 \pm 2.74$ & $15.64 \pm 2.36^{\mathrm{b}}$ \\
\hline
\end{tabular}

Note: Column data marked with different superscripts means significant difference $(\mathrm{P}<0.05)$.Column data marked with same or no superscript

Table 3 Nutritional results for different parts of beef from Chinese Simmental (\%)

\begin{tabular}{|c|c|c|c|}
\hline & Fat (\%) & Crude protein (\%) & Humidity ratio (\%) \\
\hline M.supraspinatus & $4.13 \pm 2.49^{\mathrm{ab}}$ & $21.05 \pm 1.06^{\mathrm{a}}$ & $75.13 \pm 3.87$ \\
\hline M.longissimus dorsi & $5.00 \pm 3.56^{\mathrm{b}}$ & $22.10 \pm 1.17^{\mathrm{b}}$ & $73.79 \pm 3.74$ \\
\hline M.psoas major & $4.66 \pm 2.27^{\mathrm{b}}$ & $21.88 \pm 1.42^{\mathrm{ab}}$ & $73.90 \pm 3.16$ \\
\hline M.semitendinosus & $2.28 \pm 1.04^{\mathrm{a}}$ & $22.31 \pm 0.97^{\mathrm{b}}$ & $75.75 \pm 1.96$ \\
\hline
\end{tabular}

Table 4 Sensory evaluations score for different parts of beef from Chinese Simmental

\begin{tabular}{|c|c|c|c|}
\hline & tenderness & juiciness & flavor \\
\hline M.supraspinatus & $2.81 \pm 0.48^{\mathrm{a}}$ & $2.86 \pm 0.27^{\mathrm{a}}$ & $2.78 \pm 0.36^{\mathrm{b}}$ \\
\hline M. longissimus dorsi & $2.74 \pm 0.43^{\mathrm{a}}$ & $2.89 \pm 0.30^{\mathrm{ab}}$ & $2.89 \pm 0.28^{\mathrm{b}}$ \\
\hline M.psoas major & $4.07 \pm 0.24^{\mathrm{b}}$ & $3.13 \pm 0.31^{\mathrm{b}}$ & $3.28 \pm 0.22^{\mathrm{c}}$ \\
\hline M.semitendinosus & $2.26 \pm 0.31^{\mathrm{a}}$ & $2.68 \pm 0.34^{\mathrm{a}}$ & $2.49 \pm 0.31^{\mathrm{a}}$ \\
\hline
\end{tabular}

Features research of muscle fibers on the 6 beef cattle breeds in China Xie Xiang-xue (2011) used frozen sections of muscle fiber and succinic dehydrogenase (SDH) staining method to study muscle fiber features including type, diameter, and density of longissimus dorsi, psoas major muscle, and biceps femoris muscle from 6 beef cattle breeds (Limousin, Piedmont, China Simmental, Luxi cattle, Qinchuan cattle and Jinnan cattle ) in 2011. The results showed that the proportions of red muscle fiber (type R) in longissimus dorsi of Luxi cattle and Limousin were 32.7\% and $29.5 \%$ respectively, obviously higher than that of the other four breeds $(\mathrm{P}<0.05)$; the highest proportions of type $\mathrm{R}$ fiber in psoas major muscle of Jinnan cattle and biceps femoris muscle of Luxi cattle were $42.7 \%$ and $48.7 \%$ respectively. Diameters of three types of muscle fibers in longissimus dorsi of Qinchuan cattle were $60.009,61.109$ and $67.800 \mu \mathrm{m}$, which were obviously bigger 
than that of the other five breeds $(\mathrm{P}<0.05)$; diameters of red muscle fiber (type $\mathrm{R}$ ) and intermediate fiber (type I) in psoas major muscle and biceps femoris muscle of Qinchuan cattle and Jinnan cattle were significantly larger than that of the other four breeds $(\mathrm{P}<0.05)$. Densities of red muscle fiber (type $\mathrm{R}$ ) in psoas major muscle of Piedmont and Limousin were 216.667 and 189.583 each fiber $/ \mathrm{mm}^{2}$, and densities of white muscle fiber (type R) were 200.926 and 261.11 each fiber $/ \mathrm{mm}^{2}$, both of them significantly higher than other breeds $(\mathrm{P}<0.05)$; densities of muscle fiber (type R) in longissimus dorsi and biceps femoris muscle of Luxi cattle larger than the other breeds. The proportions of different muscle fiber types in muscular tissues of different parts in the 6 cattle breeds were not regular, while for diameters of muscle fibers, except that the fiber diameter of biceps femoris muscle of Jinnan cattle was the largest, the diameters of muscle fibers (3 types) in longissimus dorsi of the other five cattle breeds were obviously bigger than that of psoas major muscle $(\mathrm{P}<0.05)$. Apart from Jinnan cattle, densities of muscle fibers in psoas major muscle of the other five cattle breeds were apparently bigger than that of longissimus dorsi and biceps femoris muscle $(\mathrm{P}<0.05)$. For various cattle breeds, there were differences among proportions of types, diameters and densities of muscle fibers in the same part. Apart from Jinnan cattle, the other five cattle breeds had the features that the density of muscle fiber in psoas major muscle was the highest, and the diameter of longissimus dorsi was larger than that of psoas major muscle, while Jinnan cattle had their own features.

There are abundant beef cattle breeds of in China; however, crossbred cattle are the major breed at present. Since 2007, China's beef cattle stocks have been declining; meanwhile the consumption for the beef has been growing year by year. China's consumers mainly have three demands for beef quality as follows: expensive beef produced from Wagyu crossbreed with better marbling; lean beef from Simmental, Charolais and Limousin crossbreeds, top parts supplied to hotels while common parts to supermarkets; veal from cow calves. Chinese researchers are carrying out researches which are centered on marbling beef, lean beef and veal on complete techniques of good breed, feeding management, slaughter and cutting and carcass classification.

\section{REPUBLIC OF SERBIA - Meat quality (crossing domestic breed $x$ beef breeds)}

One of the ways to improve the production of quality beef is a method of industrial crossing of Domestic Spotted breed with French fattening breeds. The examination included beef carcass of average weight of $42 \mathrm{~kg}$, as follows: 14 carcasses of F1 generation crosses of Domestic Spotted breed with Charolais (G1), 
18 carcasses of crosses of Domestic Spotted breed and Limousine (G2) and 25 Domestic spotted cattle carcasses (G3).

Slaughter and primary processing was performed in the experimental slaughterhouse of the Institute of Animal Husbandry. After cooling, and in the same conditions for all tested carcasses $\left(+4^{\circ} \mathrm{C}\right)$, in the next 24 hours, three rib cuts were taken from the carcass. The 9-10-11 rib cut was separated from the cooled left carcass sides, cut at the cranial edge of the 9th and 11th rib, and cut parallel to the spinal column (perpendicular to the ribs), where the $1 / 3$ of the upper rib part remained on the rib cut.

Investigation of the physical-chemical and organoleptic properties of is always conducted on the sample of $M$. longissimus dorsi (MLD), which originates from the region between 10th and 12th vertebrae. Evaluation was done by 3 assessors, and final grades ( 1 to 5) were given after consideration of individual opinion and consensus. All three judges were given equal pieces of meat in regard to the weight and muscle fibre direction and at the same temperature with the instruction to chew the same piece of meat in small pieces first with incisors teeth and in the second stage to use molars with each of them, and using the clock, to determine the duration of mastication.

Processing of experimental data was performed by the method of Least squares (LSMLMW-Harvey, 1990) according the fixed model:

$\mathrm{y}_{\mathrm{ijk}}=\mu+\mathrm{G}_{\mathrm{i}}+\mathrm{b}_{1}\left(\mathrm{x}_{1}-\mathrm{x}_{1}\right)+\mathrm{e}_{\mathrm{ijk}}$

where $G_{i}$ is the fixed effect of genotype and $b_{1}$ linear regression effect of pre slaughter weight.

Table 5. Genotype influence on MLD and $\mathrm{pH}_{24}$ value

\begin{tabular}{|lc|c|c|c|c|l|}
\cline { 2 - 6 } \multicolumn{1}{c|}{} & \multicolumn{3}{l}{$\begin{array}{l}\text { Average values }(\mu) \text { standard error (SE) and deviation from the } \\
\text { average (ci) by genotypes }\end{array}$} & \multicolumn{1}{|c}{} \\
\hline Characteristics & $\mu$ & SE & G1 & G2 & G3 & F exp. \\
\hline Colour (1-5) & 4.50 & 0.12 & 0.30 & 0.41 & -0.71 & $*$ \\
\hline Marbling (1-5) & 4.74 & 0.06 & -0.24 & 0.16 & 0.08 & NS \\
\hline Structure estimate (1-5) & 4.35 & 0.11 & 0.22 & 0.55 & -0.77 & NS \\
\hline $\mathrm{pH}_{24}$ value & 5.89 & 0.03 & -0.05 & -0.06 & 0.12 & $*$ \\
\hline
\end{tabular}

The results on the impact of genotype on the properties of MLD showed significant deviations from the general average for the colour and value of $\mathrm{pH}_{24}$ of MLD. The greatest negative deviation from the average (-0.24), for marbling was assessed in MLD of group $G_{1}$ and the largest positive deviation (0.16), in experimental group $\mathrm{G}_{2}$. The results concerning the evaluation of MLD grainy structure in Domestic Spotted breed crossed with French beef cattle breeds indicate the muscle fibre fineness, e.g. the tenderness of the meat. Meat colour of French 
beef breeds crosses is brighter red colour than in Domestic Spotted cattle. The difference in colour of meat is also confirmed by the measured values of $\mathrm{pH}_{24}$.

Table 6. Genotype influence on physical characteristics of meat

\begin{tabular}{|l|c|c|c|c|c|c|}
\cline { 2 - 6 } \multicolumn{1}{l|}{} & \multicolumn{4}{l|}{\begin{tabular}{l}
\multicolumn{1}{c}{} \\
Average values $(\mu)$, standard error (SE) and deviation from the \\
average (ci) by genotypes
\end{tabular}} \\
\hline Characteristics & $\mu$ & SE & G1 & G2 & G3 & F exp. \\
\hline Firmness (Volotkiewitsch) & 5.80 & 0.12 & -0.12 & -0.7 & 0.82 & $* *$ \\
\hline Muscle fibre diameter, $\mu \mathrm{m}$ & 46.66 & 0.61 & -1.38 & -1.84 & 3.22 & $* *$ \\
\hline Total pigment, ppm & 86.23 & 1.18 & 0.46 & 3.33 & -3.79 & $*$ \\
\hline $\begin{array}{l}\mathrm{cm}^{2} \\
\text { Muscle eye }\end{array}$ & 105.4 & 0.73 & 3.47 & -0.52 & -0.95 & $* *$ \\
\hline
\end{tabular}

Table 6 shows that the highest negative deviation from the average for the softness $(-0.12,-0.7)$ and the thickness of the muscle fibre $(-1.38,-1.84)$ was recorded in crosses of Domestic Spotted breed with French beef cattle breeds. These results indicate that the meat of these genetic groups according to their physical properties, has the softest structure. Cross-section of MLD $(+3.47)$ was the largest in genetic groups $\mathrm{G}_{1}$ i.e. in crosses Domestic Spotted breed with Charolais.

Softness ("firmness" or texture) and juiciness/succulence ("dryness") of cooked or roasted meat, and to a certain extent also aroma and flavour, are important parameters of quality of meat and are best assessed in a organoleptic/sensory examination.

Table 7. Genotype influence on organoleptic traits

\begin{tabular}{|c|c|c|c|c|c|c|}
\hline \multirow[b]{2}{*}{ Characteristics } & \multicolumn{5}{|c|}{$\begin{array}{l}\text { Average values }(\mu) \text {, standard error (SE) and deviation from the } \\
\text { average (ci) by genotypes }\end{array}$} & \multirow[b]{2}{*}{ F exp. } \\
\hline & $\mu$ & SE & G1 & G2 & G3 & \\
\hline $\begin{array}{l}(1-5) \\
\text { Cooking test - firmness }\end{array}$ & 4.48 & 0.12 & 0.38 & 0.51 & -0.89 & $* *$ \\
\hline $\begin{array}{l}(1-5) \\
\text { Cooking test - dryness }\end{array}$ & 3.57 & 0.15 & 0.27 & 0.42 & -0.69 & $* *$ \\
\hline $\begin{array}{l}(1-5) \\
\text { Cooking test - taste }\end{array}$ & 4.02 & 0.06 & 0.02 & 0.11 & -0.13 & $* *$ \\
\hline $\begin{array}{l}(1-5) \\
\text { Cooking test - aroma }\end{array}$ & 4.06 & 0.08 & -0.02 & 0.20 & -0.17 & NS \\
\hline Roasting test - firmness & 4.66 & 0.09 & 0.13 & 0.29 & -0.43 & $*$ \\
\hline $\begin{array}{l}(1-5) \\
\text { Roasting test - dryness }\end{array}$ & 3.52 & 0.08 & 0.07 & 0.38 & -0.45 & $*$ \\
\hline $\begin{array}{l}(1-5) \\
\text { Roasting test - taste }\end{array}$ & 4.05 & 0.07 & -0.11 & 0.18 & -0.06 & $*$ \\
\hline $\begin{array}{l}(1-5) \\
\text { Roasting test - aroma }\end{array}$ & 4.15 & 0.08 & -0.01 & -0.04 & 0.05 & NS \\
\hline
\end{tabular}




\section{Conclusion}

The aim of this study was to point to the possibility of improving the quality of edible meat in Domestic Spotted cattle through industrial crossing with French beef cattle breeds. Based on the obtained results, the following can be concluded:

Colour of meat from crosses of Domestic Spotted breed with Charolais and Limousine is more prominent than the meat of Domestic Spotted cattle, and these differences $(\mathrm{p}<0.05)$ were statistically significant.

The values of shear force determined by the Volotkiewitsch, indicate that meat from crosses was softer and smaller diameter muscle fibres compared to meat of Domestic spotted cattle.

\section{Acknowledgement}

This research was a part of the Bilateral Project No. 1-9, funded by the Ministry of education and science, Republic of Serbia and Ministry of science of the People Republic of China and part of the Project TR 31053 funded by the Ministry of education and science, Republic of Serbia.

\section{Efekat ukrstanja domace sarene rase sa tovnim rasama na kvalitet mesa u NR Kini i u Republici Srbiji}

S. Aleksić, Sun Fang, Liu Di, M.M. Petrović, V. Pantelic, N. Stanisic, D. Ostojić-Andrić, M. Petričević, D. Nikšić, N. Delić

\section{Rezime}

U radu su prikazani rezultati ukrštanja domaće šarene rase sa tovnim rasama u Narodnoj Republici Kini i u Republici Srbiji. Kina je zemlja sa velikom govedarskom proizvodnjom i potrošnjom. U 2012. godini, proizvodnja govedine $u$ Kini bila je 5.540.000 tona, što čini 9,7\% svetske proizvodnje goveđeg mesa, rangirana treća u svetu. Glavni izvori goveda u Kini su grla iz iz ukrštanja (nativne rase ukrštene sa stranim rasama goveda). Simentalska rasa goveda se najviše koriste u poboljšanim grlima tovne junadi u Kini. Kina je odgajila svoju simentalsku rasu, nakon više od 40 godina ukrštanja i poboljšanje. Potrošači u Kini uglavnom imaju tri zahteva koji se odnose na kvalitet mesa $i$ to: skupi goveđi proizvodi dobijeni od meleza Vagyu sa boljom marmoriranošću; odlično, nemasno 
goveđe meso grla simentalske, šarole i limuzin rase, najvredniji delovi trupa koji se isporučuju hotelima, a manje vredni delovi supermarketima; teletina koja se proizvodi od ženske teladi. Kineski istraživači su obavljali istraživanja koji su fokusirana na mramoriranost mesa, nemasnu govedinu i teletinu, na kompletne tehnike dobrof upravljanja u odgoju - rase i ishrana, klanje i rasecanje i klasifikaciju trupa. Trenutno, istraživači su su zainteresovani za genetiku funkcionalnih svojstava kvaliteta mesa goveda, oni očekuju da koriste ove metode za proučavanje osobine kvaliteta mesa, a zatim poboljšanje kvaliteta mesa. Poboljšane rase goveda koje se koriste $u$ u Kini su uglavnom simentalska, zatim šarole, limuzin, Vagyu i angus. Ostale tri rase goveda, uključujući belgijsku plavu rasu goveda, pijedmont i žutu rasu goveda se retko koriste u govedarskoj proizvodnji.

Republika Srbija u budućnosti mora da brzo i efikasno obezbedi adekvatne količine najkvalitetnijeg mesa. Jedan od načina da se poveća prinos i kvalitet mesa je ukrštanje goveda domaće šarene rase nižih proizvodnih osobina sa francuskim tovnim rasama goveda. Govedarska proizvodnja u EU je prilagođena ukusu potrošača. Meso mora da ima svetlo crvenu boju, podjednako pristnim masnim tkivom i sa izraženim senzornim karakteristikama kao što su mekoća, sočnost, ukus i aroms. Rezultati o kvalitetu mesa junadi meleza F1 generacije (domaća šarena rasa sa francuskim tovnim rasama šarole i limuzin) ukazuju da se industrijskim ukrštanjem mogu poboljšati tovne, klanične i organoleptičke osobine mesa.

\section{References}

ALEKSIĆ S., LAZAREVIĆ R., MIŠČEVIĆ B., PETROVIĆ M.M., JOSIPOVIĆ S. (1995): Proizvodni i ekonomski aspekti ukrštanja domaće šarene rase sa francuskim tovnim rasama. Tehnologija mesa, 2-3, 77-79.

ALEKSIĆ S., LAZAREVIĆ R., MIŠČEVIĆ B., PETROVIĆ M.M., JOSIPOVIĆ S. (1998): Fiksni uticaj genotipa na kvalitet junećeg mesa. Biotechnology in Animal Husbandry, 1-2, 31-39.

ALEKSIĆ S., MILICA V., MIŠČEVIĆ B., PETROVIĆ M., PERKOVIĆ S. (1999): The correlation between the distribution of carcass fatty tissue traits of meat in different genotypes of young bulls. Biotechnology in Animal Husbandry, 5-6, 1-7.

ALEKSIĆ S., LAZAREVIĆ R., MIŠČEVIĆ B., PETROVIĆ M., TOMAŠEVIĆ D. (2001): The effect of Live Weight Prior to Slaughtering on Yield and Weight of Retail Carcass Cuts. Biotechnology in Animal Husbandry, 17, 5-6, 125-133.. 
ALEKSIĆ S., PETROVIĆ M.M., MIŠČEVIĆ B., PANTELIĆ V., TOMAŠEVIĆ D., OSTOJIĆ D. (2005): Proizvodnja kvalitetnog junećeg mesa u skladu sa evropskim trendovima. Biotechnology in Animal Husbandry, 21, 5-6, 49-54.

ALEKSIĆ S., PETROVIĆ M.M., MIŠČEVIĆ B., SRETENOVIC LJ., PANTELIĆ V., TOMAŠEVIĆ D. (2006): Production of Beef Carcass According to Consumers Demands. $52^{\text {nd }}$ International Congress of Meat Science and Technology, 13-18. August 2006, Dublin, Ireland. Proceding. 541-543.

ALEKSIĆ S., PETROVIĆ M.M., PANTELIĆ V., Ž. NOVAKOVIĆ, D. TOMAŠEVIĆ , N. STANIŠIĆ, M. NOVAKOVIĆ, N. DELIĆ, M. VORKAPIĆ (2009): The effect of genotype on yield of main carcass part, Journal of Mountain Agriculture on the Balkans, 12, nu 4, p.689-70

BUCHTER: L. (1985): Danish experiences in developing and operating specifications for beef. The long term definitions of meat quality: Controlling the variability of quality in beef, veal, pig meat and lamb. Brussels, Luxemburg: Comm. Europ. Commun., 43-50.

DICKMAN M.E., POLLAK E.J., ZHANG Z., MOSER D., W., GILL C.A., DRESSLER E.A., (2005). Phenotypic ranges and relationships among carcasses and meat palatibility traits for fourteen cattle breeds, and heritability and expected progeny differences for Warne-r Bratzler shear force in three beef cattle breeds. Journal of Animal Science, 31, 75

HARRINGTON G. (1985): Review of relative importance of factor up controlling the variability of quality in beef veal, pig, meat and lamb. Brussels, Luxemburg: Comm. Europ. Commun 17-34.

ČEPIN S. (2001): Blagovne znamke govjega mesa. Meso in mesnine, 2, 17-20. ČOBIĆ T., NENADOVIĆ M., MEDIĆ D., NOVAKOVIĆ M. (1990): Ispitivanje tovnih sposobnosti muških meleza F1 generacije šaroleske i limuzinske sa simentalskom rasom goveda. Biotehnologija u stočarstvu, 3-4, 3-13.

NIU LEI, ZHANG ZHISHENG, LI HAIPENG, SUN ZHIZHONG (2011): Assessment on beef qualities of different parts of China Simmental [J]. China Husbandry and Veterinary Medicine, 38, 3, 217-219

OSTOJIC-ANDRIC D., S. ALEKSIC, HRISTOV S., NOVAKOVIC Z., M.M. PETROVIC, D. NIKSIC, N.STANISIC (2012): Serbia in the implementation of SEUROP standard for beef carcass classification: Legislation, Parameters and Evaluation Criteria (Part A). Biotechnology in Animal Husbandry 28 (1), p 47-58 WEN LIZHENG, ZHAO YUMIN, JIANG HAO (2008): Analysis on SNP of HFABP gene in improved red steppe cattle and its relation to meat quality traits. China Husbandry and Veterinary Medicine, 35 (7): 66-69

WEN LIZHENG, ZHAO YUMIN, ZHANG GUOLIANG (2008): SNP of H-FABP gene in red steppe cattle and its impact on meat quality traits. Chinese Agricultural Science Bulletin, 24 (5): 17-21 
XIE XIANGXUE, MENG QINGXIANG, REN LIPING (2011): Research on features of muscle fibers of 6 beef cattle breeds in China [J]. Journal of China Agricultural University, 16 (1): 66-72

ZHOU GUOLI, ZHU QI, GUO SHANLI (2005): Analysis on polymorphism of HFABP gene of Luxi cattle and its relation to meat quality traits [J]. Northwestern Agricultural Journal, 14:5-7

ZHOU LEI, YU QINGYUN, DU WEI (2007) Research on beef qualities of different cattle breeds, Xinjiang Agricultural Sciences, 44 (4): 534-538

Received 7 May 2013; accepted for publication 11 June 2013 